\section{Response to Dr Nikpour's letter}

We thank Dr Nikpour for her comment ${ }^{1}$ concerning our recent publication 'Remission in systemic lupus erythematosus: durable remission is rare'. ${ }^{2}$

We agree that the lupus low disease activity state (LLDAS) is associated with less long-term damage. We are convinced that true remission should be our ultimate treatment goal. For example, LLDAS allows up to $7.5 \mathrm{mg}$ of prednisone daily, while it was shown that prednisone doses above $6 \mathrm{mg} /$ day significantly increase the risk of later organ damage by $50 \% .^{3}$

Very few patients reach durable remission, regardless of defining remission on treatment or off treatment. Remission is a high bar to aim for with our current treatment strategies.

\section{Theresa R Wilhelm, ${ }^{1,2}$ Laurence S Magder, ${ }^{3}$ Michelle Petri ${ }^{1}$}

${ }^{1}$ Department of Rheumatology, Johns Hopkins University School of Medicine, Baltimore, Maryland, USA

${ }^{2}$ Videncenter for Reumatologi og Rygsygdomme, Rigshospitalet Glostrup, Glostrup, Denmark

${ }^{3}$ Department of Epidemiology and Public Health, University of Maryland, Baltimore, Maryland, USA

Correspondence to Theresa R Wilhelm, Videncenter for Reumatologi og Rygsygdomme, Rigshospitalet Glostrup, Nordre Ringvej 57, 2600 Glostrup, Denmark; theresa.rita.wilhelm@regionh.dk
Competing interests None.

Provenance and peer review Commissioned; internally peer reviewed.

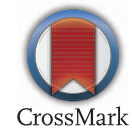

To cite Wilhelm TR, Magder LS, Petri M. Ann Rheum Dis 2016;75:e80. Accepted 5 October 2016

\section{Linked}

http://dx.doi.org/10.1136/annrheumdis-2016-210560

Ann Rheum Dis 2016;75:e80. doi:10.1136/annrheumdis-2016-210593

\section{REFERENCES}

1 Nikpour M, on behalf of the Asia Pacific Lupus Collaboration. Response to: 'Remission in systemic lupus erythematosus: durable remission is rare' by Wilhelm et al. Ann Rheum Dis 2016;75:e79.

2 Wilhelm TR, Magder LS, Petri M. Remission in systemic lupus erythematosus: durable remission is rare. Ann Rheum Dis 2016; Published Online First: 24 Aug 2016. doi:10.1136/annrheumdis-2016-209489

3 Thamer M, Hernán MA, Zhang Y, et al. Prednisone, lupus activity, and permanent organ damage. J Rheumatol 2009:36:560-4. 